\title{
Rearing of Coccinella undecimpunctata L. (Coleoptera:Coccinellidae)on two Aphid species in relation to the predator's biology
}

\author{
Mariam, R. EL- Meihy ${ }^{1}$; F. F. Shalaby ${ }^{1}$; A. A. Hafez ${ }^{\mathbf{1}}$; A.H.EL-Heneidy ${ }^{2}$ and Naglaa,F. Abdel-Hamied ${ }^{\mathbf{1}}$. \\ ${ }^{1}$ Plant Protection Department, Faculty of Agriculture, Moshtohor, Benha University, Egypt. \\ ${ }^{2}$ Biological Control Department, Plant Protection Research Institute, Giza, Egypt. \\ Corresponding Author: fawzyshalaby@yahoo.co.uk
}

\begin{abstract}
Laboratory experiments were carried out to study some biological aspects of the eleven spotted ladybird beetle, Coccinella undicempunctata L. (Coleoptera: Coccinellidae) reared on two aphid species (Aphis craccivora Koch. And Rhopalosiphum padiL.) at $25 \pm 2{ }^{\circ} \mathrm{C}$ and $65 \pm 5 \%$ R.H. A. craccivora proved as a better prey for C.undicempunctata rearing (shorter immature stages periods; 4.2,12.21,3.35 and 75.8 days for the periods of eggs incubation, larval and pupal periods and adults' longevity, respectively). The corresponding periods in case of rearing on $R$. padi were 4.72, 11.6, 3.6 and 68.4 days .The hatchability percentage among deposited eggs were 86.8 and $76.4 \%$, respectively. The pre oviposition, oviposition and post oviposition periods were 5.4 , 61.1 and 9.3 days on $A$. craccivora , opposed to $12.4,49.5$ and 6.5 days on $R$. padi. .
\end{abstract}

Key words: Biology ,Coccinella undecimpunctata , Aphis craccivora, Rhopalosiphum padi.

\section{Introduction}

The ladybird beetles (Coleoptera: Coccinellidae) have been known worldwide as predators of a number of insects. Also, they have a very distinctive shape and can be easily identified (Watts, 2004). Larval and adult stages are very good predators of aphids and other small insects and mites (Hangay and Zborowski, 2010). When there is a fine excess of aphids fed to beetles they always lay little or vast bunches of eggs (Dixon, 2000). The insects of Coccinellidae family are very gracious and valuable. These are predators of many other insects that help farmers in controlling the crop damaging insects below threshold level (Vincent et.al., 2007).

The eleven spotted lady beetle, aphidophagous species, Coccinella undecimpunctata $\mathrm{L}$. is one of the most important predators for the effective control of aphids beside other insect species .Both adult and larvaeare considered as potential predators of a wide range of prey, as well as aphids (Cabral et. al., 2006 and Ali et al.,2017).

Aphids are difficult to control due to their extremely high fecundity. They reproduce partheno genetically; i.e., females reproduce without fertilization. A female aphid produces 50-100 nymphs throughout its life span. The newly laid nymphs reach the adult stage and begin reproducing in 6-8 days (Short, 1993).

Faba bean aphid, Aphis fabae (Scopoli) (Hemiptera: Aphididae) is a cosmopolitan polyphagous pest (Dixon, 1998). According to Ibrahim (1955) the fecundity of $C$. undicempunctatais affected by the quality of food eaten, so there is a positive correlation between qualities of food consumed and egg production. The biology of Coccinella undecimpunctataL. fed on cowpea aphid, Aphis craccivora has been studied by Imam (2015) under laboratory conditions $\left(25 \pm 5^{\circ} \mathrm{C}\right.$ and $60 \pm 5 \%$ R.H.). The results revealed that a single female laid $195.0 \pm 13.10$ eggs during entire life period. The egghatching was $96.3 \%$ while $82.0 \%$ of larvae survived up to pupal stage. Total larval and pupal durations were $23.4 \pm 0.35$ and $5.3 \pm 0.56$ days, respectively. Mean percentemergence in male and female were $36.6 \pm 2.98$ and $56.6 \pm 4.21$, respectively.

The present study was carried out to evaluate the biology and feeding capacity of $C$. undecimpunctata when it was reared on two species of aphids as natural preys under laboratory conditions.

\section{Materials and Methods}

\section{Biological studies-}

All experiments were carried out in the laboratory of biological control at the Plant Protection Dept., Faculty of Agriculture Moshtohor, Benha University , under the laboratory conditions of $25 \pm 2{ }^{\circ} \mathrm{C}$ and $65 \pm 5 \%$ R.H.

\section{Aphid culture-}

\section{Rearing of Rhopalosiphum padi L.}

Infested wheat seedlings with $R$. padi individuals were translocated to clean un infested wheat seedlings in the laboratory and kept under the lab. conditions. Rearing of $R$. padi was carried out in 2 steps:

1-Grains of wheat were planted in plastic pots no. $12(12 \mathrm{~cm}$ diameter and $9 \mathrm{~cm}$ height) containing wet sawdust.These pots were placed also in muslin screen cages and kept in the laboratory. The pots were supplied daily with water spray until germination of wheat grains and appearance of the seedlings. New infestations of fresh seedlings by $R$. padi were repeated every three days to insure enough quantities of aphids as prey for coccinellids during the whole period of experiment.

2-The growing seedlings were infested by $R$. padi by placing heavily infested ones .The aphids left the 
wilting seedlings and moved to infest and multiply on the growing fresh seedlings.

2-The legume aphid, Aphis craccivora Koch:

Stock culture of this aphid species was maintained in the laboratory on faba bean seedlings. Broad bean (Vicia faba) seeds were planted in wet sawdust placed in plastic pots (no. 14) $(14 \mathrm{~cm}$ diameter and $11 \mathrm{~cm}$ height). The seeds were sown at $1-2 \mathrm{~cm}$ depth and followed with daily irrigation .Containers were placed in muslin screen cages and kept in the laboratory conditions. Once the first leaves of new seedlings started to appear, old infested faba been leaves were cut and placed between new seedlings .Soonafter that, (within few hours) the aphids move and climb to the new seedlings and multiplied on them .Dense culture of this aphid, soon, became available. So, enough quantities of the aphid were always available for feeding the ladybird beetles.

-Stock culture of the coccinellid predator, Coccinellaundecimpunctata

Adults of $C$. undecimpunctata were collected from faba bean fields at Moshtohor, Qalubiya Governorate and transferred to the laboratory.

\section{-Rearing of C.undecimpunctata}

1-Five pairs (males and females) of $C$. undicempunctata were placed in a glass chimney cage, covered on the top with muslin cloth pieces fixed in position with rubber bands. The glass chimney cages were placed on pots with some faba bean seedlings provided with strips of black paper for egg-laying. The predators were provided daily with fresh faba bean leaves infested with adequate numbers of $A$. craccivora individuals to serve as food. Female adults deposited their eggs either on the leaves of faba bean seedlings or on the black paper strips.

2-The deposited eggs were, daily collected, counted and placed in Petri-dishes for rearing the predator.

3- Neonate larvae of the predator were provided, daily, with adequate numbers of aphids, until pupation. Resultant pupae were kept in jars until adults' emergence.

The same technique was followed for rearing thepredator on $R$. padi.

\section{-Biological characteristics of $C$. undecimpunctata 1-Incubation period of eggs and hatchability:}

Five groups of freshly deposited eggs, 50 each, from females that were reared on the natural preys (R.padi and A. craccivora) under the laboratory conditions of $25 \pm 2{ }^{\circ} \mathrm{C}$ and $65 \pm 5 \% \quad$ R.H. were transferred to clean plastic cups $(8 \mathrm{~cm}$ diameter and $4 \mathrm{~cm}$ height ) until hatching. At the time of hatching the incubation period of eggs was estimated among eggs of each group. Percentage of egg hatching and those failed to hatch were calculated. Pre- ovipositional, ovipositional and post- ovipositional periods as well as longevity of females were calculated.

\section{2-Duration of larval and pupal stages:}

For estimating the larval and pupal durations, a group of 10 neonate $C$. undecimpunctata larvae were placed, individually, in plastic cups lined with filter paper. Each larva was daily provided with enough number of $4^{\text {th }}$ nymphal instar of aphid (starting with 10 nymphs /larva/day). The offered nymphs were increased as the larvae grew older (5 nymphs every day ).The duration of each larval instar and the total larval period were estimated and recorded.As the larvae pupated and $C$. undecimpunctata adults emerged , the pupal period and percentage of adults' emergence were estimated .

\section{Statistical analysis.}

The statistical analysis was carried out using ANOVA, under significance level at 0.05 , using SAS software ( SAS, 2003).

\section{Results and Discussion}

\section{I- Biological characteristics of C.undecimpunctata:} Durations of immature stages

Data presented in tables (1\&2) show the durations of $C$. undicempunctata immature stages when the predator was fed on two natural prey species (A. craccivora and $R$. padi) under the laboratory conditions.

\section{a- Effect of preys on egg stage}

-Incubation period of eggsand hatchability, and mortality percentages

As shown in table, (1) and fig. (1), the averages of the incubation period of $C$. undecimpunctata eggs were 4.20 and 4.72 days when reared on A. craccivora and $R$. padi, respectively. Shortest incubation period (4.20 days) was insignificantly shorter than that recorded on $R$. padi (4.72 days).

For hatchability percentages of the deposited eggs , those recorded after rearing on $A$. craccivora and $R$. padi were 86.80 and $76.40 \%$, respectively.The highest hatching percentage $(86.80 \pm 1.33 \%)$ resulted in eggs deposited after rearing on A. craccivora, being nonsignificantly higher than that occurred after rearing on $R$. padi $(76.40 \pm 1.33 \%)$. Consequently, the mortality percentage among these eggs varied significantly .In this respect, Mari, et al.,2016revealed thatthe hatching percent of eggs of C. undecimpunctata was $70.21,68.11$, and $66.03 \%$ when reared on maize, alfalfa, and mustard aphids under laboratory conditions but the values were nonsignificant. They, also,stated thatthe mean incubation period of $C$. undecimpunctata eggs laid by females reared on maize, alfalfa, and mustard aphids were $6.5,8.20$, and 7.0 days, respectively with nonsignificant (chi-square value (0.039) at 0.05 level). 
Table 1. Incubation period of eggs and percentages of egg hatchability of $C$. undecimpunctata after rearing on two aphid species under laboratory conditions $\left(25 \pm 2 \mathrm{C}^{\circ}\right.$ and $65 \pm 5 \%$ R.H.)

\begin{tabular}{|c|c|c|c|}
\hline Preys & Incubation period (days) & Hatchability (\%) & Mortality (\%) (unhatched) \\
\hline \multirow[t]{2}{*}{ A. craccivora } & $4.20 \pm 0.09^{b}$ & $86.80 \pm 1.33^{a}$ & $13.20 \pm 1.33^{b}$ \\
\hline & $(4.0-4.5)$ & $(84.0-90.0)$ & $(10.0-16.0)$ \\
\hline \multirow[t]{2}{*}{ R. padi } & $4.72 \pm 0.11^{\mathrm{a}}$ & $76.40 \pm 1.33^{b}$ & $23.60 \pm 1.33^{a}$ \\
\hline & $(4.4-5.0)$ & $(72.0-80.0)$ & $(20.0-28.0)$ \\
\hline
\end{tabular}

**A, B \& C: There is non-significant difference $(\mathrm{P}>0.05)$ between any two means for the same attribute, within the same column have the same superscript letter.

*Data presented as means \pm standered error

*Data from (250 eggs / treatment).

\section{$\square$ A. cracivora $\square R$. padi}

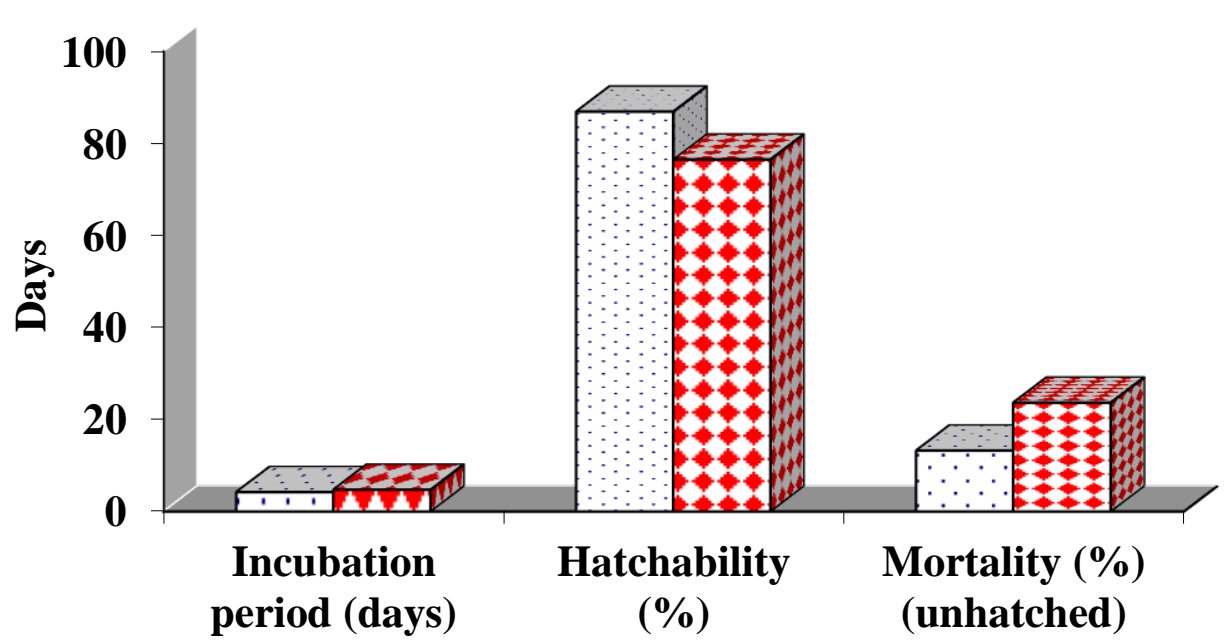

Fig.1. Incubation period of eggs and percentages of egg hatchability of $C$. undicempunctata after rearing on two aphid species under laboratory conditions.

\section{b- Effect of prey species on larval stage}

The durations of the 4 larval instars of $C$. undecimpunctata under two different temperatures. (20 and $25^{\circ} \mathrm{C}$ ) are given in table (2) and fig.(2).Data show that the mean duration of the $1^{\text {st }}$ instar larva of the predator lasted;3.40 $\pm \mathbf{0 . 1 6}$ and $\mathbf{2 . 7 0 \pm 0 . 2 0}$ days, when fed on $A$. craccivora nymphs and $3.50 \pm 0.15$

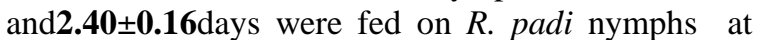
20 and $25^{\circ} \mathrm{C}$,respectively). The respective mean durations of the $2^{\text {nd }}$ larval instar were $3.56 \pm 0.15$ and 2.95 \pm 0.09 days, when fed on $A$. craccivora and 3.67 $\pm \mathbf{0 . 1 7}$ and $\mathbf{2 . 8 0 \pm 0 . 0 8}$ days, when fed on $R$. padi, the $3{ }^{\text {rd }}$ instar larval duration lasted; $\mathbf{3 . 8 3} \pm \mathbf{0 . 2 0}$ and 3.17 \pm 0.12 days when fed on $A$. craccivora and 3.94 \pm 0.06 and $3.10 \pm 0.07$ days, when fed on $R$. padi Mean durations of the $4^{\text {th }}$ larval instars of were 4.33 \pm 0.29 and $3.44 \pm 0.19$ days, when fed on $A$. craccivora and $4.39 \pm 0.16$ and $3.30 \pm 0.15$ on $R$. padi at 20 and $25^{\circ} \mathrm{C}$,respectively . Mari, et al., 2016 revealed that feeding on different host aphids did not significantly influence the duration of various life stages of $C$. undecimpunctata. Whereas, the duration values in days for first, second, third and fourth instars averaged 6.50, 5.60, 7.90 and 8.01 days, respectively on maize aphid, Rhopalosiphum maidis. For alfalfa aphid, Therioaphis trifolii, it averaged $5.25,6.0,6.10$ and 7.80 days, respectively. The duration averaged 5.23, 5.66, 5.91 and 8.50 days, respectively on mustard aphid, Lipaphis erysimi.
Imam, 2015 indicated that mean durations of 1st, 2nd, 3rd and 4th larval of $C$. undecimpunctata instars were $3.2 \pm 0.51,5.1 \pm 0.35,6.5 \pm 0.56$ and $8.6 \pm 0.22$ days, respectively.

\section{Total larval period:}

The total larvalperiod of $C$. undecimpunctata was not influenced by the prey species used, but influenced by the rearing temp. Average periods of 15.08 and 12.21days were reported for the total larval periods associated with the prey A. craccivora under two different temp.(20and 25$)^{\circ} \mathrm{C}$, respectively. While theywere 15.46and 11.60days by feeding on $R$. padi. Data concerning total larval durations showed the same trend of the effectiveness of different preys and temp. on $C$. undecimpunctata larval durations. Imam, 2015 revealed that total larval and pupal durations of $C$. undecimpunctata were $23.4 \pm 0.35$ and $5.3 \pm 0.56$ days, respectively on $A$. craccivora .

Ingeneral, the effect of different tested preys on larval instars durations and total larval period was non-significant .On the other hand, the degree of temp. showed a significant effect on the larval periods i. e. duration of reared larvae at $20^{\circ}$ was significantly longer than those reared at $25^{\circ}$.

\section{C- Effect of prey species on Pupal duration.}

At $(20 \text { and } 25)^{\circ} \mathrm{C}$ and $65 \pm 5 \%$ R.H., the pupal periods of $C$. undecimpunctata ranged from3.35 to 
4.67 days for pupae resulted after feeding on $A$. craccivora, while it ranged 3.60 to $\mathbf{4 . 7 8}$ days for pupae resulted after feeding on $R$. padi this (Table 2and fig.2).

Insignificant effect of two different prey species on the pupal stage was reported comparing to the effect of temp.which showed significant deviation in between. Similar observationswerenoticed by other workers such as Imam, 2015 who reported that the total larval and pupal durations of $C$. undecimpunctata were $23.4 \pm 0.35$ and $5.3 \pm 0.56$ days. Also, Debaraj and Singh , 1990 reported that the pupal stage lasted from 3-12 days depending upon availability of food and temperature.

Table 2. Durations of various larval instars and pupal stage of $C$. undecimpunctata reared on two aphid species under two different temperature

\begin{tabular}{|c|c|c|c|c|c|c|c|c|}
\hline \multirow[b]{2}{*}{ 2 } & \multirow{2}{*}{$\begin{array}{l}\text { Temperature } \\
\left({ }^{\circ} \mathrm{C}\right)\end{array}$} & \multicolumn{4}{|c|}{ Duration of larval instars (days) } & \multirow{2}{*}{$\begin{array}{c}\text { Total } \\
\text { larval } \\
\text { period }\end{array}$} & \multirow[b]{2}{*}{ Mean } & \multirow{2}{*}{$\begin{array}{l}\text { Pupal } \\
\text { period }\end{array}$} \\
\hline & & $1^{\text {st }}$ & $2^{\text {nd }}$ & $3^{\text {rd }}$ & $4^{\text {th }}$ & & & \\
\hline \multirow{2}{*}{ 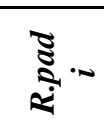 } & 20 & $\begin{array}{l}3.50 \pm 0.15^{\mathrm{aC}} \\
(3-4)\end{array}$ & $\begin{array}{l}3.67 \pm 0.17^{\mathrm{aBC}} \\
(3-4)\end{array}$ & $\begin{array}{l}3.94 \pm 0.06^{\mathrm{aB}} \\
(3.5-4)\end{array}$ & $\begin{array}{l}\text { 4.39 } \pm 0.16 a A \\
(4-5)\end{array}$ & $15.46 \pm 0.35 \mathrm{a}$ & $3.86 \pm 0.09^{\mathrm{a}}$ & $\begin{array}{c}4.78 \pm 0.09^{\mathrm{a}} \\
(4.5-5)\end{array}$ \\
\hline & 25 & $\begin{array}{l}2.40 \pm 0.16^{b C} \\
(2-3)\end{array}$ & $\begin{array}{l}2.80 \pm 0.08^{\text {bB }} \\
(2.5-3)\end{array}$ & $\begin{array}{l}3.10 \pm 0.07^{\mathrm{bA}} \\
(3-3.5)\end{array}$ & $\begin{array}{l}3.30 \pm 0.15^{\mathrm{bA}} \\
(3-4)\end{array}$ & $11.60 \pm 0.32^{b}$ & $2.90 \pm 0.08^{b}$ & $\begin{array}{c}3.60 \pm 0.10^{b} \\
(3-4)\end{array}$ \\
\hline \multirow{2}{*}{ 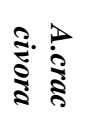 } & 20 & $\begin{array}{l}3.40 \pm 0.16^{\mathrm{aC}} \\
(3-4)\end{array}$ & $\begin{array}{l}3.56 \pm 0.15^{\mathrm{aBC}} \\
(3-4)\end{array}$ & $\begin{array}{l}3.83 \pm 0.20^{\mathrm{aB}} \\
(3-5)\end{array}$ & $\begin{array}{l}4.33 \pm 0.29^{\mathrm{aA}} \\
(3-5)\end{array}$ & $15.08 \pm 0.46^{\mathrm{a}}$ & $3.77 \pm 0.12^{\mathrm{a}}$ & $\begin{array}{c}4.67 \pm 0.17^{\mathrm{a}} \\
(4-5)\end{array}$ \\
\hline & 25 & $\begin{array}{l}2.70 \pm 0.20^{\mathrm{bC}} \\
(2-4)\end{array}$ & $\begin{array}{l}2.95 \pm 0.09^{\mathrm{bBC}} \\
(2.5-3.5)\end{array}$ & $\begin{array}{l}3.17 \pm 0.12^{\mathrm{bA}} \\
(3-4)\end{array}$ & $\begin{array}{l}3.44 \pm 0.19^{\mathrm{bA}} \\
(2.5-4)\end{array}$ & $12.21 \pm 0.35^{b}$ & $3.05 \pm 0.09^{b}$ & $\begin{array}{c}3.35 \pm 0.40^{b} \\
(3-4.5)\end{array}$ \\
\hline
\end{tabular}

$\mathrm{a}, \mathrm{b} \& \mathrm{c}$ : There is no significant difference $(\mathrm{P}>0.05)$ between any two means, within the same column have the same superscript letter.

A, B \& C: There is no significant difference $(\mathrm{P}>0.05)$ between any two means for the same attribute, within the same row have the same superscript letter.

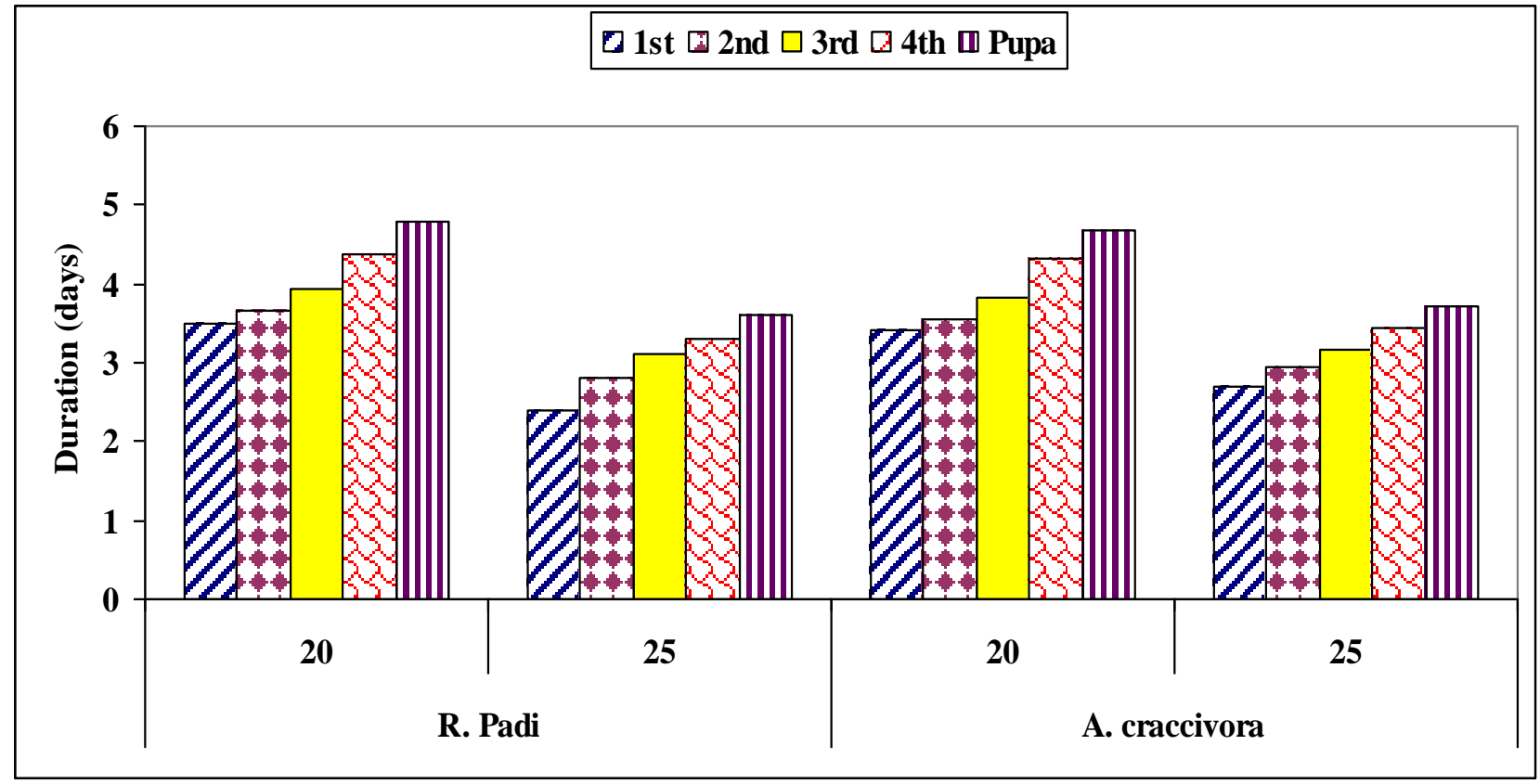

Fig.2: Durations of four larval instars and pupae of $C$. undecimpunctata reared on two natural preys under two different temperatures.

D-Effect of preys on ovipositional periods and longevity of $C$. undecimpunctata

\section{-Ovipositional periods}

-Pre - ovipositional period

As shown in table (3) and Fig.(3), preovipositional period of $C$. undecimpunctata females avarged5.40 $\pm 0.31(4-6.5)$ days in case of A.craccivora nymphs, being significantly shorter $12.40 \pm 0.92$ (5-8days) than on $R$. padi nymphs . .In this respect,Mari,et al.,2016 revealed that the preovipositional periods of the predatorwere4.02, 3.51 and 3.91 days, when on Rhopalosiphum maidis,
Therioaphis trifolii and, Lipaphis erysimi, respectively.

\section{-Ovipositional period}

The ovipositional period of $C$. undecimpunctata female was significantly longer $61.10 \pm 3.14$ days $(45$ $75)$ for those fed on $A$. craccivora nymphs and 49.50 \pm 2.74 days (39-62)for females after rearing on $R$. padi (Table $3 \&$ fig. 3).In this respect,Mari, et al.,2016 revealed that the ovipositional periods were 24.22, 25.41 and 23.62 days, for Rhopalosiphum maidis, Therioaphis trifolii, and Lipaphis erysimi.

-Post ovipostional period 
As shown in table (3) the post-ovipositional period of the predator female was significantly longer, $9.30 \pm 0.52$ days (7-12) than the $6.50 \pm 0.28(8-17)$ when females were reared on $A$. craccivora and $R$. padi nymphs, respectively .In this respect,Mari, $\boldsymbol{e t}$ al.,2016 revealed that the post-ovipositional periods in days were 4.66, 4.50 and 3.99 for Rhopalosiphum maidis Therioaphis trifolii, and Lipaphis erysimi.

\section{-Longevity}

As shown in table (3), the longevity was significantly longer $\mathbf{7 5 . 8 0} \pm 3.37(60.5-91.0)$ than the 68.40 \pm 3.58 (54.0-83.0) when $C$. undecimpunctata was reared on A. craccivora and R.padi nymphs, respectively .Mari et al., 2016 revealed that life span of $C$. undecimpunctata were $35,50.00$, and 40.00 days for females and 30.00, 42.00 and 32.00 days for males when reared on Rhopalosiphum maidis, Therioaphis trifolii, and Lipaphis erysimi, respectively .

Table 3. Mean $\pm \mathrm{SE}$ and ranges of $C$. undecimpunctata ovipositional periods recorded by rearing it on the $4^{\text {th }}$ instar nymph of two aphid species at $25 \pm 2^{\circ} \mathrm{Cand} 65 \pm 5 \mathrm{R} . \mathrm{H}$

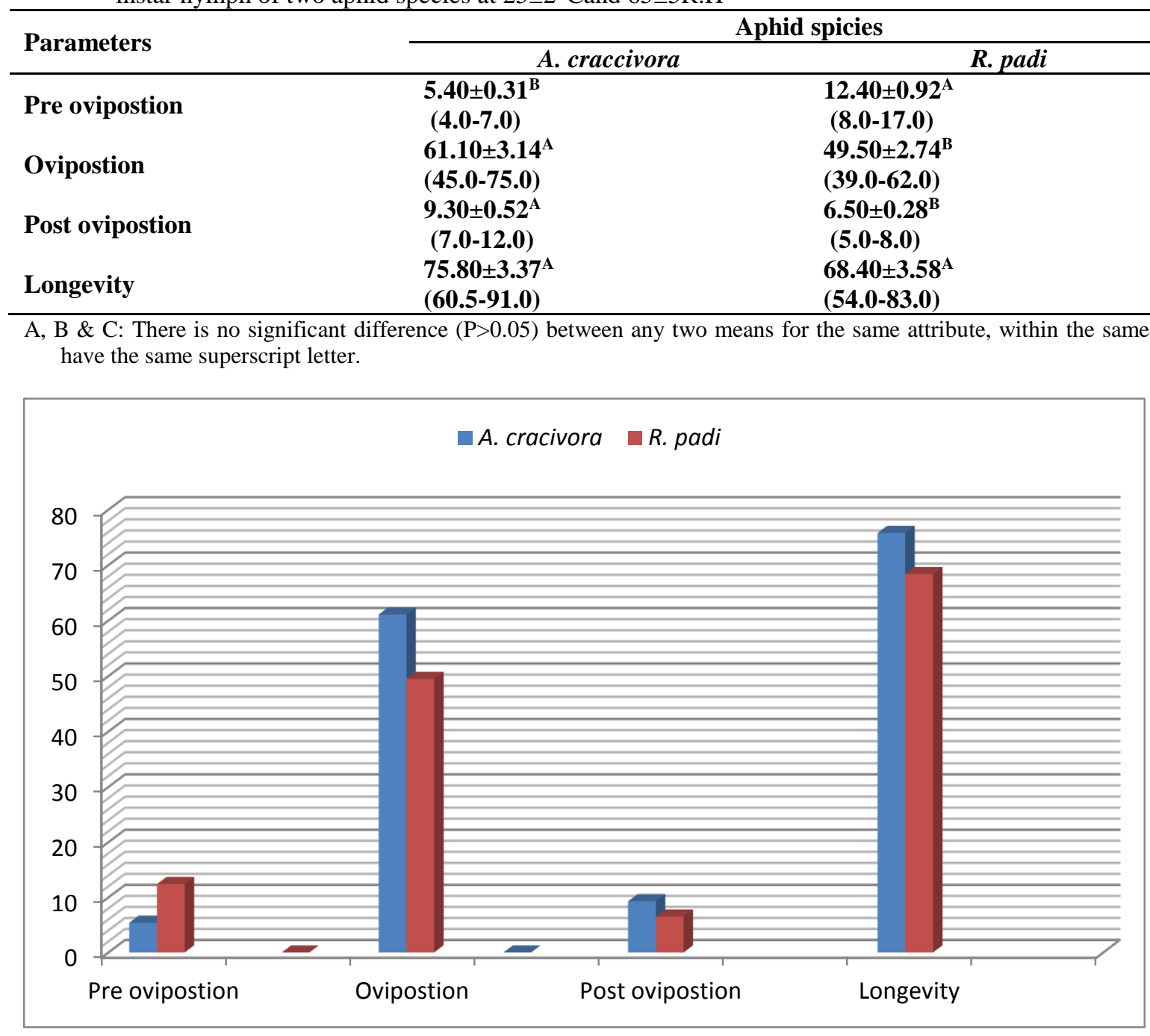

Fig. 3. Ovipositional periods of $C$. undecimpunctatafed on the $4^{\text {th }}$ nymphalinstar of two aphid speciesat $25 \pm 2^{\circ}$ Cand $65 \pm 5 \mathrm{R} . \mathrm{H}$.

\section{References}

Andrews, M. and Hodge, S. 2010. Climate change, a challenge for cool season grain legume crop production. In: Yadav SS, Redden R, Editors. Climate Change and Management of Cool Season Grain Legume Crops. pp. 1-9. Springer.
Ali, A.;Shafique,A. M.; Abdul, H. M.; Mehar-unNisa N.; Azizullah, M.A. and Saghir, A. 2017. Biology and feeding potential of ladybird beetle (Coccinellaseptempunctata)aginst different species of aphids.Sci.Int.(Lahore),29(6),12611263,2017.

Cabral, S.; Soares,A.O;Moura, R and Garcia, P. 2006. Suitability of Aphis fabae, 
Myzuspersicae (Homoptera: Aphididae) and Aleyrodesproletella (Homoptera: Aleyrodidae) as prey for Coccinellaundecimpunctata(Coleoptera:

Coccinellidae). Biol. Control, 39:434-440.

Debaraj, Y. and Singh, T. K. 1990. Biology on an aphidophagousCoccinella predator, Coccinellatranversalis. J. biol. Cont., 4: 9395.

Dixon, A. F. G. 1998. Aphid ecology: an optimization approach. Chapman and Hall, springer .

Dixon, A.F.G. 2000. Insect predator-prey dynamics. Ladybird beetles and biological control.University of East Anglia. Cambridge University Press, pp. 1.

Hangay, G. and Zborowski, P. A. 2010. Guide to the Beetles of Australia, Csiro Publishing.

Ibrahim, M. M. 1955. Studies on Coccinella undecimpunctata its biology and life history. Bull. Soc. Entom., Egypt, pp: 395-423.

Imam, I. 2015. Biological characteristic of eleven spot ladybird Coccinellaundecimpunctata
(Linnaeus), reared on cowpea aphid, Aphis craccivora (Koch), under laboratory conditions .J. Plant Prot. and Path., Mansoura Univ., Vol. 6 (6): 909 - 914.

Mari, J. M.; Ghulam, A. B.; Wang, B. and Cao, N. 2016. Biological parameters and preferential feeding response of Coccinellaundecimpunctata $\mathrm{L}$. on three aphid species.Journal of Entomology and Zoology Studies; 4(4): 1306-1310

Obrycki, J. J. and Kring, T. J. 1998.Predacious Coccinellidae in biological control. Annual Review of Entomology 43(1), 295-321.

SAS .2003. Statistical analysis system. SAS user's guide: statistics. SAS Inc. Editors ,cary, Nc

Short, D. E. 1993. Aphids on ornamental plants around the home. http://edis.ifas.ufl.edu.

Vincent, C.; Goettel ,M.S. and Lazarovits, G. 2007. Biological Control. A Global Perspective, Cabi.

Watts, B. 2004. Beetles (Keeping Minibeasts) 5th edition, SeaTo-Sea Publications. 29.

\section{العلاقه بين بيولوجي أبي العيد 11 نقطه والتربيه علي نوعين مختلفين من حشرات المن}

أجريت تجارب معمليه لدراسه بعض الصفات البيولوجيه لخنفساء أبي العيد 11 نقطه Coccinella undicempunctata L التابع لرنبة Co

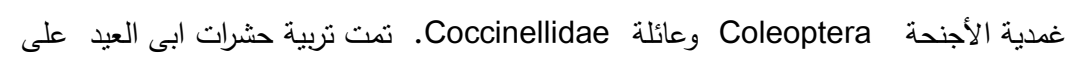

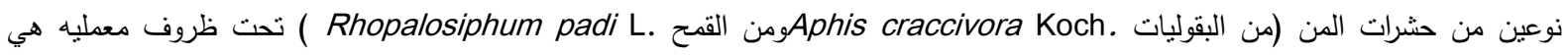



أعطت تربيه المفترس الحشري علي افراد من البقوليات المتوسط , لفترات حضانه البيض , العمر اليرقي , طور العذراء وفتره حياة الحشره الكامله , علي التوالي) , مقابل

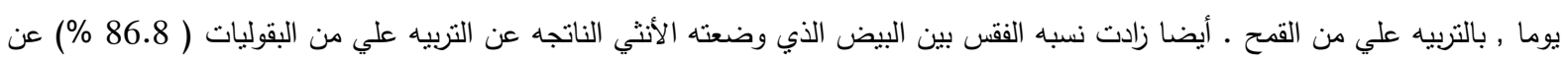
تللك الناتج من التربيه علي من القمح (76.4\%). أما فترات ما قبل وضع البيض , وضع البيض وما بعد وضع البيض فبلغت منوسطاتها ( 5.4

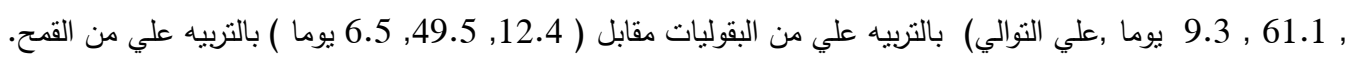

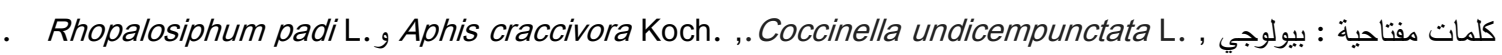

